\section{Brief Communication}

\section{Check for updates}

\title{
Outbreak associated with Rotavirus G11,P[25] in Korea in 2018
}

\author{
Su-Jin Chae (D), Sunyoung Jung $(\mathbb{D}$, Seung-Rye Cho $\mathbb{( D )}$, Wooyoung Choi $\mathbb{D}$, and \\ Deog-Yong Lee (1)
}

OPEN ACCESS

Received: May 25, 2020

Accepted: Nov 5, 2020

Corresponding Author:

Deog-Yong Lee, PhD, DVM

Division of Viral Diseases, Center for Laboratory Control of Infectious Diseases, Korea Centers for Disease Control and Prevention, 187 Osongsaengmyeong 2(i)-ro, Heungdeok-gu, Cheongju 28159, Korea. Tel: +82-43-719-8194

Fax: +82-43-719-8219

E-mail: leedy0610@korea.kr

Copyright $(\subset 2020$ by The Korean Society of Infectious Diseases, Korean Society for Antimicrobial Therapy, and The Korean Society for AIDS

This is an Open Access article distributed under the terms of the Creative Commons Attribution Non-Commercial License (https:// creativecommons.org/licenses/by-nc/4.0/) which permits unrestricted non-commercial use, distribution, and reproduction in any medium, provided the original work is properly cited.

ORCID iDs

Su-Jin Chae (iD

https://orcid.org/0000-0002-5147-8843

Sunyoung Jung (D)

https://orcid.org/0000-0001-9179-4085

Seung-Rye Cho (iD)

https://orcid.org/0000-0002-1635-4837

Wooyoung Choi (D)

https://orcid.org/0000-0002-5857-3149

Deog-Yong Lee (iD)

https://orcid.org/0000-0003-4481-4789

Conflict of Interest

No conflicts of interest.
Division of Viral Diseases, Center for Laboratory Control of Infectious Diseases, Korea Centers for Disease Control and Prevention, Osong, Korea

\section{ABSTRACT}

We here report the first outbreak caused by rotavirus G11,P [25] in Korea in 2018, representing a case of re-assortment with pig-derived rotavirus. The genotype constellation was identical to the virus identified in Korea in 2012 as G11-P[25] -I12-R1-C1-M1-A1-N1-T1-E1-H1. The infection source was not known exactly but it must be considered infection from swine.

Keywords: Rotavirus G11,P[25]; Pig-derived rotavirus; Genotype constellation; Infection source

Rotavirus is a major pathogen of pediatric diarrhea and causes infections mainly in children under 5 years of age. Sometimes, rotaviruses from pigs and cows were known to cause human infection. In particular, G11 type derived from pig was known to cause recombination with $\mathrm{P}[6], \mathrm{P}[8]$, and P[25] [1]. Recently, there has been an outbreak caused by rotavirus G11, P[25] recombined with pig-derived rotavirus in Korea. In this study, we investigated the molecular epidemiologic characteristics of outbreak of rotavirus G11, P[25].

Outbreak occurred in junior high school students who completed training at a training center in Geoje-si, Gyeongnam Province, Korea. The number of students was 575 from middle schools located in Gyeongnam Province and Busan Metropolitan City. The training process was carried out 3 days, and clinical symptom were observed 3 days after the training. The main symptoms were diarrhea, vomiting and fever. Cases were defined as cases with diarrhea symptoms more than 3 times a day. According to case definition, the incidence of clinical symptoms was 111 patients $(19.3 \%$ ) of a total of 575 exposed people. The residences in the training center varied from 7 to 20 people, and drinking water was used for chlorinated groundwater. The water tank was able to accommodate 50 tons and was operated by installing one chlorine dispenser, but no additional control was made after installation two years ago. Most of the food was cooked and some unheated foods were provided by the training center (Table 1).

To identify causative pathogens, fecal specimens were collected from the 111 patients and groundwater and preserved foods were collected to keep track of contamination sources. Case-related samples were obtained and analyzed according to the law of infectious disease prevention and management. Therefore, there was no additional IRB review. The pathogens 
Author Contributions

Conceptualization: DYL. Writing - Original Draft: SJC. Investigation: SJC, SJ, SRC. Writing - Review \& Editing: WC.

\begin{tabular}{|c|c|c|c|}
\hline Day & 1st & 2nd & 3rd \\
\hline \multirow[t]{6}{*}{ Breakfast } & & Rice & Rice \\
\hline & & Beef Soup & Sea Mustard Soup \\
\hline & & Egg Roll & Fried Pork with kimchi \\
\hline & & Seasoned Laver & Seasoned dried-Laver \\
\hline & & Fried ham and vegetable & Stir-fried Fish Cake \\
\hline & & Kimchi & Kimchi \\
\hline \multirow[t]{6}{*}{ Lunch } & & Rice & Rice \\
\hline & & Seafood miso stew & Soybean Paste Soup with Dried Radish Leaves \\
\hline & & Pork Cutlet & Sweet and Sour Pork \\
\hline & & Stir-fried Rice cake & Seasoned Bean Sprouts \\
\hline & & Buttercup herb & Salad with Vegetable and razor-clam Meat \\
\hline & & Kimchi & Kimchi \\
\hline \multirow[t]{6}{*}{ Dinner } & Rice & Rice & \\
\hline & Tuna Kimchi Stew & Fish Cake Soup & \\
\hline & Fried vegetables & Stir-fried Anchovies & \\
\hline & Stir-fried Pork & Chicken Stew & \\
\hline & Stewed Potatoes & Shredded Daikon & \\
\hline & Kimchi & Kimchi & \\
\hline
\end{tabular}

Foods using porks as ingredients are marked in bolded letter.

to be tested were 10 species of bacteria and 5 species of virus, and they were inspected by the local health and environment research institutes in accordance with the "Practical Guidelines for Diagnosis of Waterborne Foodborne Diseases" [2]. Rotavirus was identified by EIA and norovirus was by real-time RT-PCR. In human specimens, 15 cases of rotavirus and 1 case of norovirus were detected, but no pathogen was detected in groundwater and preserved food tests. Rotavirus was confirmed to be non - rotavirus by one sample in the genetic test, and the final 14 cases were determined as positive. Genotyping tests were performed according to the World Health Organization recommended protocol on human specimens confirmed to be rotavirus. All 14 samples were identified as G11, P[25] [3].

The genotypes of eleven gene segments were confirmed by re-extracting nucleic acid from 14 specimens identified as rotavirus G11, P[25]. Genes were amplified for each segment, and the genotype was confirmed by the Rota $\mathrm{C} v 1.0$ that web based rotavirus classification tool (http://rotac.regatools.be) [4]. The relationship between rotavirus was analyzed by Clustal W using the MEGA v6.0 software (http://megasoftware.net). The genotype constellation of rotavirus detected in the outbreak was finally determined as G11-P[25] -I12-R1-C1-M1-A1-N1T1-E1-H1 (Table 2). Above all, VP6 has been identified as genotype I12, similar to other virus identified in Korea in 2012 [5]. However, all the patients reported in the two regions formed the same cluster, but the difference between the cases confirmed in domestic (Hu / CAU12-2, [5]) and the reference gene (Hu / KTM368, [6]) in the relational analysis (Fig. 1).

Table 2. Comparison of genomic constellation of human rotavirus, porcine rotavirus and outbreak cases

\begin{tabular}{|c|c|c|c|c|c|c|c|c|c|c|c|c|}
\hline Strains & VP7 & VP4 & VP6 & VP1 & VP2 & VP3 & NSP1 & NSP2 & NSP3 & NSP4 & NSP5 & References \\
\hline $\mathrm{Hu} / \mathrm{Wa}$ & G1 & $\mathrm{P}[8]$ & 11 & $\mathrm{R} 1$ & $\mathrm{C} 1$ & M1 & $\mathrm{A} 1$ & N1 & $\mathrm{T} 1$ & E1 & $\mathrm{H} 1$ & \\
\hline $\mathrm{Hu} / \mathrm{KTM} 368$ & G11 & $\mathrm{P}[25]$ & 112 & $\mathrm{R} 1$ & $\mathrm{C} 1$ & M1 & $\mathrm{A} 1$ & N1 & $\mathrm{T} 1$ & E1 & $\mathrm{H} 1$ & \\
\hline Hu/Dhaka6 & G11 & $\mathrm{P}[25]$ & 11 & $\mathrm{R} 1$ & $\mathrm{C} 1$ & M1 & $\mathrm{A} 1$ & N1 & $\mathrm{T} 1$ & E1 & $\mathrm{H} 1$ & [6] \\
\hline $\mathrm{Hu} /$ Matlab36-02 & G11 & $\mathrm{P}[8]$ & 11 & $\mathrm{R} 1$ & $\mathrm{C} 1$ & M1 & $\mathrm{A} 1$ & N1 & $\mathrm{T1}$ & E1 & $\mathrm{H} 1$ & \\
\hline $\mathrm{Po} / \mathrm{YM}$ & G11 & $\mathrm{P}[7]$ & 15 & $\mathrm{R} 1$ & $\mathrm{C} 1$ & M1 & A8 & N1 & $\mathrm{T} 1$ & E1 & $\mathrm{H} 1$ & \\
\hline Po/Gottfried & G4 & $\mathrm{P}[6]$ & 11 & $\mathrm{R} 1$ & $\mathrm{C} 1$ & M1 & A8 & N1 & $\mathrm{T} 1$ & E1 & $\mathrm{H} 1$ & \\
\hline Po/Osu & G5 & $\mathrm{P}[7]$ & 15 & $\mathrm{R} 1$ & $\mathrm{C} 1$ & M1 & $\mathrm{A} 1$ & N1 & $\mathrm{T} 1$ & E1 & $\mathrm{H} 1$ & \\
\hline $\mathrm{Hu} / \mathrm{CAU12-2}$ & G11 & $\mathrm{P}[25]$ & 112 & $\mathrm{R} 1$ & $\mathrm{C} 1$ & M1 & $\mathrm{A} 1$ & N1 & $\mathrm{T1}$ & E1 & $\mathrm{H} 1$ & {$[5]$} \\
\hline BS-18-04-0004 & G11 & $\mathrm{P}[25]$ & 112 & $\mathrm{R} 1$ & $\mathrm{C} 1$ & M1 & $\mathrm{A} 1$ & N1 & $\mathrm{T} 1$ & E1 & $\mathrm{H} 1$ & In this study \\
\hline
\end{tabular}


A

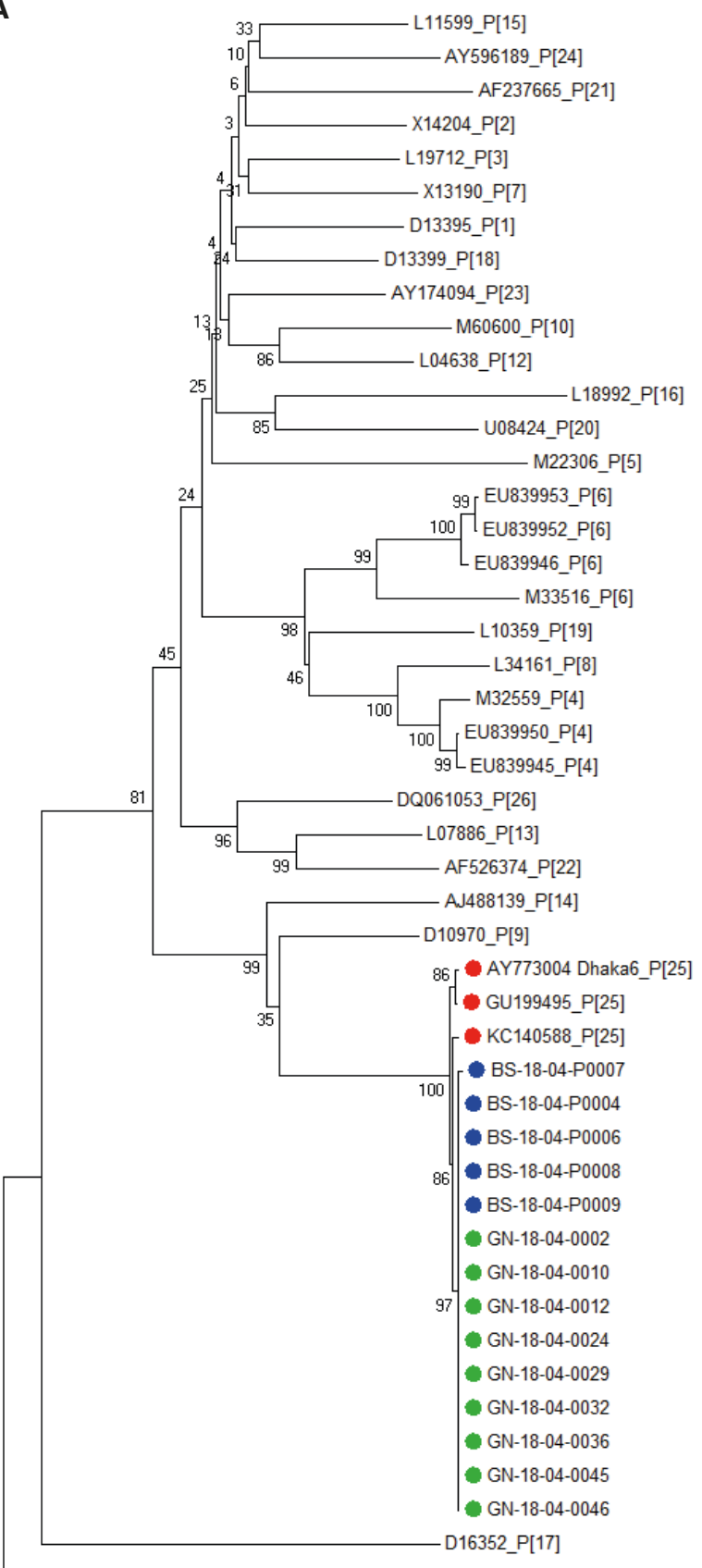

$\longmapsto .1$
B

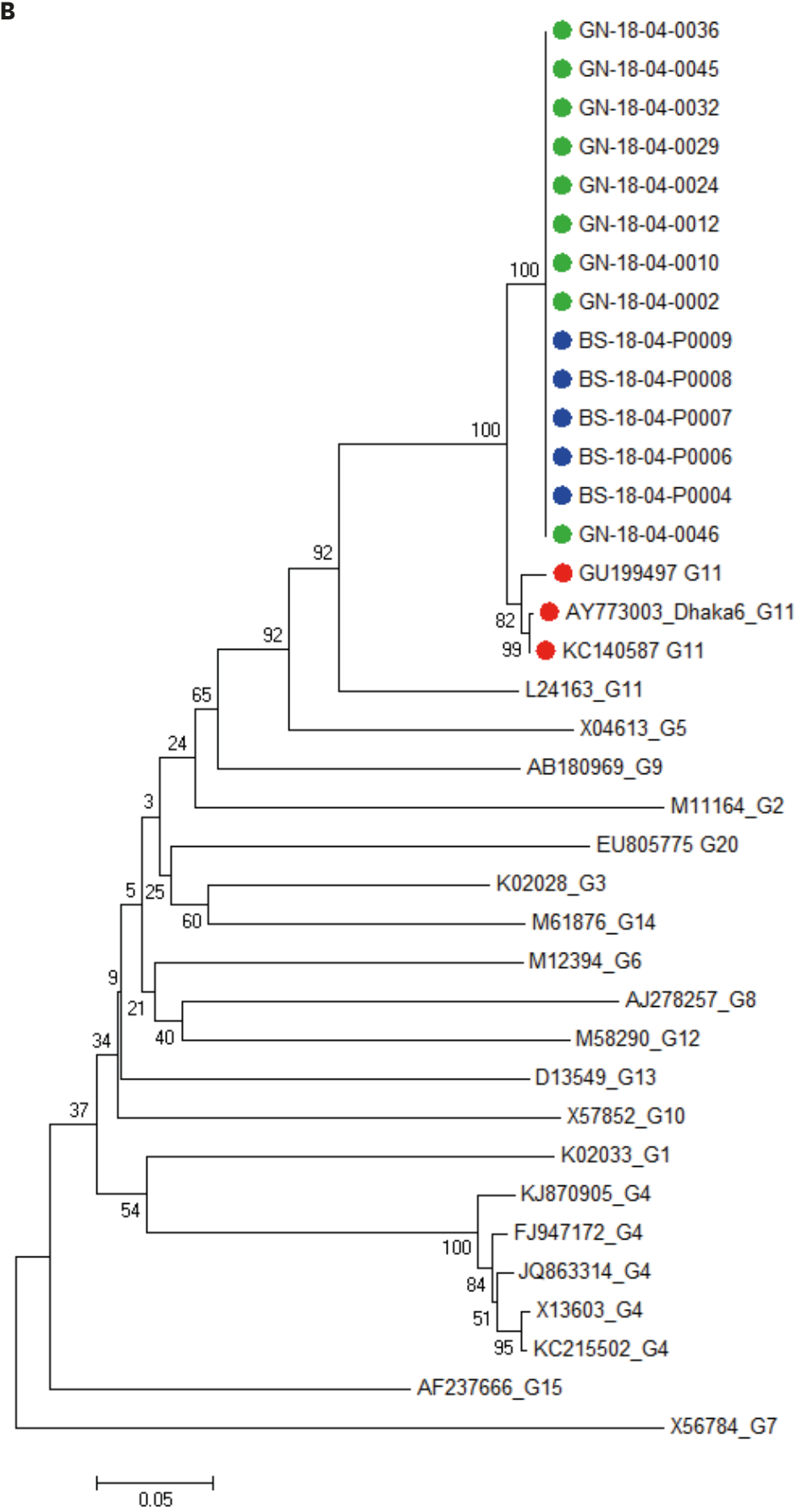

Figure 1. Phylogenetic Analysis of Patients with Rotavirus.

Rotaviruses reported in the two regions formed the same cluster, but differ from the reference genes. (A) Phylogenetic tree of VP4, (B) Phylogenetic tree of VP7.

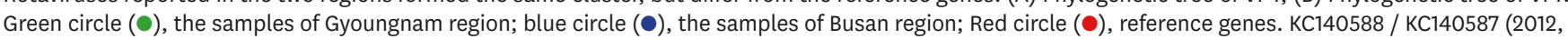
Korea), AY773004 / AY773003_Dhaka6 (2001, Dhaka, Bangladesh), GU199495 / GU199497 (2004, Kathmandu, Nepal). 
laboratory surveillance (EnterNet-Korea) [11], and thereafter another case report [5]. There was no report of other infections caused by pig-derived rotavirus other than infection by G11, P[4], which is known to be the same pig-derived rotavirus [1]. All of these were single infected cases.

In the course of the investigation, the possibility of food-borne propagation was considered to be extremely low for most of the food was cooked. However, even though laboratory tests did not detect rotavirus, it is unlikely that the infection caused by pork could be ruled out. Because there were 4 kinds of foods that used pork as a material out of 36 kinds of food that was offered 6 times in total for 3 days. We could not directly prove that the rotavirus was derived from pigs in this study. However, the results of genetic analysis suggest that swinederived virus such as rotavirus G11,P[25] are likely to be in constant circulation.

\section{ACKNOWLEDGEMENTS}

This study was supported by acute diarrheal laboratory surveillance system (EnterNet-Korea) in Korea CDC (4851-304-210).

\section{REFERENCES}

1. Hong SK, Lee SG, Lee SA, Kang JH, Lee JH, Kim JH, Kim DS, Kim HM, Jang YT, Ma SH, Kim SY, Paik SY. Characterization of a G11,P [4] strain of human rotavirus isolated in South Korea. J Clin Microbiol 2007;45:3759-61. PUBMED | CROSSREF

2. Korea Center for Disease Control and Prevention (KCDC). Laboratory diagnostic practice guide for food and water-borne disease. Available at: http://www.kdca.go.kr/board/board.es?mid=a20507020000\&bid= 0019. Accessed 20 July 2017.

3. World Health Organization (WHO). Manual of rotavirus detection and characterization methods. Available at: https://apps.who.int/iris/bitstream/handle/10665/70122. Accessed October 2009.

4. Maes P, Matthijnssens J, Rahman M, Van Ranst M. RotaC: a web-based tool for the complete genome classification of group A rotaviruses. BMC Microbiol 2009;9:238. PUBMED | CROSSREF

5. Than VT, Park JH, Chung IS, Kim JB, Kim W. Whole-genome sequence analysis of a Korean G11P[25] rotavirus strain identifies several porcine-human reassortant events. Arch Virol 2013;158:2385-93. PUBMED | CROSSREF

6. Matthijnssens J, Rahman M, Ciarlet M, Zeller M, Heylen E, Nakagomi T, Uchida R, Hassan Z, Azim T, Nakagomi O, Van Ranst M. Reassortment of human rotavirus gene segments into G11 rotavirus strains. Emerg Infect Dis 2010;16:625-30. PUBMED | CROSSREF

7. Rahman M, Matthijnssens J, Nahar S, Podder G, Sack DA, Azim T, Van Ranst M. Characterization of a novel P[25],G11 human group a rotavirus. J Clin Microbiol 2005;43:3208-12. PUBMED | CROSSREF

8. Uchida R, Pandey BD, Sherchand JB, Ahmed K, Yokoo M, Nakagomi T, Cuevas LE, Cunliffe NA, Hart CA, Nakagomi O. Molecular epidemiology of rotavirus diarrhea among children and adults in Nepal: detection of G12 strains with P[6] or P[8] and a G11P[25] strain. J Clin Microbiol 2006;44:3499-505. PUBMED | CROSSREF

9. Banerjee I, Iturriza-Gomara M, Rajendran P, Primrose B, Ramani S, Gray JJ, Brown DW, Kang G. Molecular characterization of G11P[25] and G3P[3] human rotavirus strains associated with asymptomatic infection in South India. J Med Virol 2007;79:1768-74. PUBMED | CROSSREF 
10. Mullick S, Mukherjee A, Ghosh S, Pazhani GP, Sur D, Manna B, Nataro JP, Levine MM, Ramamurthy T, Chawla-Sarkar M. Genomic analysis of human rotavirus strains G6P[14] and G11P[25] isolated from Kolkata in 2009 reveals interspecies transmission and complex reassortment events. Infect Genet Evol 2013;14:15-21. PUBMED | CROSSREF

11. Kim SH, Cheon DS, Jeong HS, Kim MJ, Kee HY, Seo JJ, Kim TS, Kim ES, Park JT, Chung JK. Distribution of group A rotavirus genotypes circulating in Gwangju, Korea. J Bacteriol Virol 2009;39:21-8. CROSSREF 